\title{
17
}

\section{Some Comments on the Gradual Inclusion of Musics beyond the Western Canon by Selected Universities and Societies}

\section{Barbara B. Smith}

\section{Introduction}

Stephen Wild's 'Encountering the World of Music: The University's Widening Acknowledgment of Music beyond the Western Canonic Repertoire' in The Australian National University School of Music's 2015 lecture series is another of his insightful papers about music in Australia. Throughout the years I have been privileged to know him, his papers have challenged me to consider if and how something analogous to what he presented might benefit the ethnomusicology programme at the University of Hawai' $\mathrm{i}(\mathrm{UH})$, as well as more broadly to what ethnomusicology should be and do. In reading this 2015 paper, I was surprised by the credit given to the hosting of conferences and other meetings of national and international societies for enlarging the scope of music embraced by The Australian National University (ANU). I had recognised that faculty members benefited professionally from participation, and that often, through them, their institutions benefited. However, this was not the same as their more direct role at the School of Music at the ANU. Pondering how these differed led to recalling how some music education 
and scholarly societies came to broaden the scope of their interest and activities beyond those for which they were established. Although this chapter can only touch on some of them, I hope my comments may be of interest to Stephen. However, before turning to these, I want to thank him for what, for me, has been a highly valued relationship that began in $1980^{1}$ at the silver-anniversary meeting of the Society for Ethnomusicology (SEM). There, in the session on Oceania, he presented a paper titled 'A Perspective on Australian Aboriginal Ethnomusicology', as well as one in the session that had been planned for Alan Merriam to deliver the annual distinguished lecture (Wild 1982). Our relationship has continued and grown through activities of the International Council for Traditional Music (ICTM) and its Study Group for Musics of Oceania (now Study Group on Music and Dance of Oceania), ${ }^{2}$ and in other ways.

\section{Three American universities}

In the geographic areas colonised by Great Britain, including the United States of America (USA) and Australia, it is not surprising that when the colonisers established educational institutions for their children, they taught the music then taught in England, which was Western music. Nor is it surprising that little or no conscious attention was given to the musical expressions of the indigenous inhabitants of their new settlements or to other parts of the world. Of the many American universities with ethnomusicology programmes, I limit my comments here to three whose programmes began in the 1960s, commenting first on the two that Stephen has aptly described as having 'rival' ethnomusicology programmes: Indiana University and the University of California, Los Angeles (UCLA).

In retrospect, it seems preordained that a prominent programme for study would be developed at Indiana University with methodology developed through and appropriate to music of non-literate peoples following the appointment of the consummate scholar Alan Merriam as professor of anthropology in 1962. Indiana's Folklore Institute already housed the Archives of Folk and Primitive Music (later renamed Archives of

1 I had heard of him as a young scholar with outstanding potential, when he was about to enter Indiana University to pursue the doctorate, but had no chance to meet him before this conference.

2 Among these, I deeply appreciate his contributing Chapter 13 (Wild 2001) to a volume in my honour (Lawrence and Niles 2001). 
Traditional Music) that George Herzog had brought there several years after his 1948 appointment as professor of anthropology and director of the Folklore Institute. Merriam had earned the PhD in anthropology at Northwestern University in 1951, where he studied with Richard A. Waterman and M. J. Herskovits, and conducted fieldwork among Native Americans (at the time called 'American Indians') in Montana and in two cultures of Africa. His books, The Anthropology of Music (1964) and Ethnomusicology of the Flathead Indians (1967) quickly became exceedingly influential.

Likewise in retrospect, it seems preordained that a pre-eminent programme in ethnomusicology with a focus on methodology for the study of nonWestern high-art music would be established at UCLA following the appointment of the multitalented academic Mantle Hood to its faculty in 1956. Hood had earned the BA and MA in music composition at UCLA, then began the study of non-Western music for the doctorate under Jaap Kunst at the University of Amsterdam (Hood 1954), followed by two years of fieldwork in Java and Bali. In 1958 Hood acquired a fine Javanese gamelan for UCLA and began teaching its performance. In 1960 he directed the remarkable Festival of Oriental Music and Related Arts (often considered the beginning of UCLA's ethnomusicology programme), followed in 1961 by the establishment of the renowned Institute for Ethnomusicology. The Institute, through the financial resources of a large foundation grant, offered students the opportunity to study several highart (mostly Asian) traditions with outstanding performer-bearers of several genres with the expectation that they develop proficiency in a genre's performance. Hood's 1969 article 'The Challenge of "Bi-Musicality"'which presents his rationale for requiring competence in Western music before undertaking academic study of another high-art music coupled with the acquisition of competence in performance in that genrewas highly influential, as was his book The Ethnomusicologist (1971).

In the 1950s, the music department of the third institution, the University of Hawai $i$, offered only the BA, and the majority of its students were earning the BEd in preparation for teaching in Hawai' i's public elementary and high schools. Virtually all of them were locally born of Hawaiian or Asian ancestries. In response to finding that some of them lacked self-respect because their academic studies were exclusively 'white' (i.e. Euro-American) and they were not, in 1957 a lecture-type course about the traditional musics of all the ancestral heritages of Hawai'i's multiethnic population was developed and taught. 
Then, believing that all children in Hawai' $i$ should have a multimusical experience beginning in elementary school and to enable both students preparing to teach and these schools' in-service teachers to provide that, I began co-teaching our new course 'Pacific and Asian Music in Music Education' together with Dorothy Kahananui Gillett in the summer of 1959. By 1961, our grass-roots approach had led to the establishment of the MA in music with a concentration in ethnomusicology. Numerous performance groups are a feature of the programme, and reflect the cultural diversity of Hawai' i. Although all three universities have expanded their ethnomusicology programmes since the days of their founding, the initial focus of each continues as a prominent feature.

\section{Three music education societies}

The organisations I comment on here are those with which my personal experience began in the 1950s and 1960s, including two American ones that may have counterparts in other countries. My comments focus primarily on 'international' aspects of their activities, although that term may not appear in their names.

The International Society for Music Education (ISME) was founded in 1953 at the International Conference on the Role and Place of Music in the Education of Youth and Adults, convened in Brussels, Belgium, by UNESCO in collaboration with the International Music Council (IMC). In preparation for the conference, UNESCO first asked IMC to consider ways through which music could contribute to its broad mission of increasing understanding and cooperation among the world's peoples. It then asked a small committee (that included Charles Seeger) to design a conference that would lead to their implementation (UNESCO 1955). For that purpose, the majority of the morning and afternoon sessions were devoted to meetings of three 'working commissions', each to focus on a specified aspect and recommend means for action. ${ }^{3}$ There were also plenary sessions, concerts, film sessions, and a book and instrument exhibit. The plenary sessions were devoted to appropriate international protocols (there were participants from more than 30 countries, although, of the more than 250 participants, the vast majority were from Europe

3 While in Europe that summer and although not a participant, I attended three days of the conference. I met and talked with some participants, heard performances, and spent considerable time in the book and instrument exhibit. 
and the USA). The reading of papers focused on then current conditions in several countries and regions. One session concerned a reading and discussion of Seeger's proposal (Seeger 1955), and a final day was devoted to a report of the Rapporteur General, adoption of resolutions, and formal closure of the conference.

The attractively printed schedule distributed at the conference provided not only the names and countries of speakers, and the names and conductors of the 24 choral and six instrumental performance groups, but also the repertoire they would perform, which, with the exception of several arrangements of 'negro spirituals', was entirely of Western folk or classical music. Although not listed in it, there were invitational receptions and other activities. One of these comprised several meetings of a small, select group of delegates for planning what interim positions would be needed and who to appoint to them to organise the first meeting of the new entity and to choose sites for its first decade of alternate-year conferences. Although those meetings were closed to other participants, it became known that there was some reluctance to accept the invitation of the Japanese delegate to hold the 1963 ISME conference in Tokyo, even though the Japanese delegate assured them that, given 10 years, Tokyo would be ready and able to host it. I had also been surprised to find in the book exhibit that, in contrast to the book series published for school use in the USA, those for European countries contained only their own country's songs. These two observations led me to the conclusion that at least some European delegates must have been more interested in using the new organisation as a vehicle to spread knowledge and appreciation of their own music than to learning about the indigenous music of nonWestern countries. ${ }^{4}$

For the 1963 conference in Tokyo, the local arrangements committee presented fine performances of Western concert music played by Japanese musicians, and one of quite advanced Western solo compositions for violin, played simultaneously by a large group of young Japanese children trained through the Suzuki method. It also presented concerts of an impressive range of traditional Japanese music, clearly demonstrating that the Japanese people were actively and effectively engaged in the music of both the West and their own traditional heritage. In spite of this,

4 By then I had felt it would be helpful to the UH programme for me to join ISME, so I participated in it (Smith 1963) and arranged for all the participants in a UH study tour on 'Music in Asia', for which I was the director, to attend it. 
by the end of the 1980s, only four other conferences were held outside of Europe (Carthage, Tunisia, in 1973; Perth, Australia, in 1974; Eugene, Oregon, USA, in 1984; and Canberra, Australia, in 1988), and only the last of these gave significant attention to the indigenous music of the host country. It was only in 1990 that a committee was appointed to “'do something” about world music' (Nettl 2010) that crafted a policy statement (presumably what was mailed to its members in an attractively printed, non-dated item about the time of the 1998 conference in Pretoria, South Africa). ${ }^{5}$ As adopted by the board in 2006, a core value stated: 'in teaching the musics of the world, the integrity of each music and its value criteria should be fully respected' (International Society for Music Education 2006).

The Music Educators National Conference (MENC), now known as the National Association for Music Education (NAfME), ${ }^{6}$ is the predominant American organisation concerned with music education. It now has more than 130,000 members, region divisions, and state and local chapters. It is also ISME's USA National Affiliate. Some presentations on Hawaiian ${ }^{7}$ and Asian music had been included in its Western Division's conferences and these and other non-Western musics at its national conferences. Also at the national level, a few articles about non-Western musics had been published in its Music Educators Journal. However, both the 10th Biennial Convention of its Western Division held in Honolulu in 1969, with its principal focus the music and dance of the Pacific Islands and Asia, and the vol. 59, no. 2 issue (1972) of the journal that embraced musics of the whole world were major milestones for music education in the USA. ${ }^{8}$

5 Also the publication in 1998 of Musics of the World's Cultures: A Source Book for Music Educators by Barbara Lundquist and C. K. Szego, the preparation for which had been supported by ISME's Board and Advisory Panel, coincided with the conference in Pretoria.

6 In 1907 the Music Supervisors National Conference was founded; the name changed in 1934 to Music Educators National Conference (MENC). Later, only its acronym was used until 2011, when it was again changed to NAfME.

7 By Dorothy Kahananui and her daughter Dorothy Kahananui Gillett. After having joined MENC, by 1934 Dorothy Kahananui had co-founded and served as first president of the Hawai' $\mathrm{i}$ Music Educator's Association (HMEA). HMEA became the Territory of Hawai' i's sub-area section of MENC's California 'group' and held monthly meetings until December 1941, when the USA entered World War II. By 1949, high school music teachers felt the need for an entity associated with MENC, so Kahananui became deeply involved with a revival of HMEA that was to become the Territory of Hawai' i Chapter of MENC.

8 Articles from this issue were reprinted as a book for classroom use, Music in World Cultures (Music Educators National Conference 1972). 
The College Music Society (CMS) was founded in 1957 to provide a forum for consideration of all music concentrations (which were then all of Western music). In 1967, it added a representative for each of the several areas of concentration to its executive board, including one for ethnomusicology. Soon after that, its yearly journal invited a few articles about college programmes, one of which was $\mathrm{UH}$ with its ethnomusicology component (Smith 1971). For its 1971 annual meeting, ${ }^{9}$ I was asked to organise a panel on non-Western music. I also arranged an evening concert of some traditional and some recently composed music for traditional Asian instruments. In 1995, CMS established an International Meetings Committee to organise a meeting in each odd-numbered year in a country other than USA or Canada. The first two meetings were held in Germany and Austria. When Ricardo Trimillos became committee chair, the range of meeting sites was expanded to include some non-Western locations, including Kyoto, Japan (1999), San José and Muelle, Costa Rica (2003), and Bangkok and Ayutthaya, Thailand (2007).

\section{Two scholarly societies}

The International Folk Music Council (IFMC) was founded in 1947 and renamed the International Council for Traditional Music (ICTM) in 1991. I participated in its 11th conference held in Liège, Belgium, in 1958 (Smith 1959). During a short stay in London en route home, I went to its office to learn about the council's history. There Maud Karpeles, its secretary who had been so significant to its founding, told me that she had previously been very active in the English Folk Dance Society. When it combined with the English Folk Song Society she found it to be dominated by men who severely restricted women's participation in any performance of dance. In response she became active in the founding of IFMC, whose focus included European folk song and dance. Between its founding and 1958, its annual meetings were largely in European countries, although it had met once in the USA (in Indiana in conjunction with the American Folklore Society) and once in São Paulo, Brazil, where the Western canon had become so well established as to dominate the music scene in its major urban centres. Karpeles seemed delighted to learn that as an elementary

9 The focus of this meeting held in San Francisco was the need for universality in college education in the 1970s (Smith 1971). 
school student I had been taught and enjoyed performing some English folk songs and dances, and as a college student had attended a series of lectures about Cecil Sharp with whom she had conducted some research.

Perhaps that encounter in her office made her remember me: in the 1961 business meeting of the conference in Quebec, I was among the majority who voted to hold the 1966 meeting in Legon, Ghana, rather than the site of her choice. She took notice, and as we passed each other in the hallway she chided me for having done so. It is to her credit that in 1966 in Ghana, rather than expressing any lingering disappointment for meeting in Africa, following A. K. Deku's welcoming address in the opening session (Deku 1967) that I considered so prescient about the direction IFMC was just beginning to take, her response to the hosts (Karpeles 1967) and her behaviour in public were models of gratitude and appreciation. In contrast to this, in a candid moment and just to me as we waited to leave Legon to attend a performance in a more traditional setting, she told me how strongly she disliked 'this horrible African music'. Clearly for her, it was more important to do what was best for the council than to convey her negative view to those for whom it was a highly valued treasure.

The Society for Ethnomusicology (SEM), an American society with a large international membership, was formally founded in 1955, but was already in discussion by 1953. Of its four founders-Alan Merriam, David McAllester, Willard Rhodes, and Charles Seeger—all but Seeger had been active in studying music of Native Americans. A widely circulated storyplausible, even if apocryphal-about its founding was that after papers about American Indian music they proposed for presentation at a meeting of the American Musicological Society (AMS) ${ }^{10}$ had been rejected by its programme committee as inappropriate, they arranged to meet Seeger to discuss starting a new organisation for ethnomusicology. Willard Rhodes's 'A Short History of the Founding of SEM' (1980) presents a far different account of it. Whichever it really was, when first established, SEM's

10 AMS was founded in 1934 to advance scholarly research on music. One of its eight founders was Helen H. Roberts, whose research included music in several American Indian communities, in Jamaica, and in Hawai $i$ that led to her great contribution to knowledge of the music of a Pacific Islands people: Ancient Hawaiian Music (1928). In retrospect, it seems likely that AMS might have expanded to embrace non-Western music except that Roberts's gender (like that of Maud Karpeles in England) seems to have limited her influence. Furthermore, the expertise and interests of the influx of European musicologists, who immigrated to the US to avoid persecution by the Nazis, were in the Western canon (except for Curt Sachs), and they quickly became influential to the aims and priorities of AMS. Whatever the reasons, AMS gave no significant attention to any American music in annual conferences until 1976, when it did so in recognition of the 200th anniversary of the founding of the USA. 
predominant focus was music of non-literate peoples, and when Mantle Hood joined it and wanted its primary focus to be on music as sound product rather than social context, the two approaches collided before melding and the benefits of its disciplinary origins and methodologies could be realised. SEM's continued incorporation of methodologies of other disciplines (initially linguistics) and broadening its range of music studied beyond that of 'the long ago and the far away' (initially the music of urban minorities and marginalised resident populations) were accomplished in response to changes in American society. This has differentiated it not only from ICTM but also from the original intent when founded-a process that continues today. ${ }^{11}$

\section{Conclusion}

In this personal account beginning almost seven decades ago, the USA experience in ethnomusicology and the Australian one described by Stephen seem to follow a similar trajectory, though each with its own distinctive set of events, personalities, and timings of their institutional structures. Like Stephen, I appreciate the dynamism of our field of enquiry, and look forward to its continuing development in the hands of the coming generation of scholars and colleagues. Also like Stephen, I am encouraged by the ever-widening engagement of our universities and educational and scholarly societies with the many musics of the world. It is now time for Stephen to enjoy his accomplishments and to celebrate those of his students. It is also time for us to honour him as our colleague.

11 With only a small membership in the years immediately after its founding, it is not surprising that its earliest annual meetings were held jointly with other organisations: in 1956 with the International Congress of Anthropological and Ethnological Sciences (in which members of the American Anthropological Association (AAA) were deeply involved); in 1957 with AAA; and 1958 through 1960 with AMS. Its first meeting without such collaborations was in 1961. In total, from its founding through 2015, only 36 of its annual meetings were held alone; all the others were held jointly with one or several of 16 other organisations (some national, some local to the area in which a meeting was held). Although SEM is the US National Committee of the ICTM, the first joint gathering between both organisations - a symposium with a few invited members from each — was held in Ireland in 2015. 


\section{References cited}

Deku, A. K. 1967. 'Opening Address.' Journal of the International Folk Music Council 19: 6-8.

Hood, Mantle. 1954. The Nuclear Theme as Determinant of Patet in Javanese Music. Groningen: J. B. Walters.

_. 1969. 'The Challenge of "Bi-Musicality".' Ethnomusicology 4 (2): $55-59$.

—. 1971. The Ethnomusicologist. New York: McGraw-Hill Book Co.

International Society for Music Education. 2006. [Mission and Core Values]. Accessed 20 December 2015. www.isme.org/about.

Karpeles, Maud. 1967. 'Address.' Journal of the International Folk Music Council 19: 9.

Lawrence, Helen Reeves, and Don Niles. 2001. eds. Tradition and Modernity in the Music and Dance of Oceania: Essays in Honour of Barbara B. Smith. Oceania Monograph, 52. Sydney: University of Sydney.

Lundquist, Barbara, and C. K. Szego. 1998. Musics of the World's Cultures: A Source Book for Music Educators. Reading, UK: International Society for Music Education.

Merriam, Alan P. 1964. The Anthropology of Music. Evanston: Northwestern University Press.

-1967. Ethnomusicology of the Flathead Indians. Chicago: Aldine.

Music Educators National Conference. 1972. 'Music in World Cultures.' Special issue, Music Educators Journal 59 (2).

Nettl, Bruno. 2010. 'Music Education and Ethnomusicology: A (Usually) Harmonious Relationship.' Keynote address to 2010 ISME conference in Beijing. Accessed 20 December 2015. official-isme.blogspot.com/ 2010/12/keynote-address-by-bruno-nettl-beijing.html.

Rhodes, Willard. 1980. 'A Short History of the Founding of SEM.' Accessed 20 December 2015. www.ethnomusicology.org/?page= History_Founding. 
Roberts, Helen H. 1928. Ancient Hawaiian Music. Bernice Pauahi Bishop Museum Bulletin, 29. Honolulu: Bishop Museum.

Seeger, Charles. 1955. 'A Proposal to Found an International Society for Music Education.' In Music in Education: International Conference on the Role and Place of Music in the Education of Youth and Adults, Brussels, 29 June to 9 July 1953, 325-31. Paris: UNESCO.

Smith, Barbara B. 1959. Folk Music in Hawaii.'Journal of the International Folk Music Council 11: 50-55. doi.org/10.2307/834858.

- _ 1963. 'Asian and Pacific Music in Hawaiian Music Education.' Report [International Conference on the Role and Place of Music in the Education of Youth and Adults. Fifth Conference of the International Society for Music Education], 194-98. Tokyo: International Society for Music Education.

- 1971. 'Ethnomusicology in the Undergraduate Program at the University of Hawaii.' College Music Society Symposium 11: 51-54.

UNESCO. 1955. Music in Education: International Conference on the Role and Place of Music in the Education of Youth and Adults, Brussels, 29 June to 9 July 1953. Paris: UNESCO.

Wild, Stephen A. 1982. 'Alan P. Merriam: Professor.' Ethnomusicology 26 (1): 91-98.

—_. 2001. 'Forty Years of Facilitating: The Role of the Australian Institute of Aboriginal and Torres Strait Islander Studies in Research on Indigenous Music and Dance in Australia.' In Traditionalism and Modernity in the Music and Dance of Oceania: Essays in Honour of Barbara B. Smith, edited by Helen Reeves Lawrence and Don Niles, 165-75. Oceania Monographs, 52. Sydney: University of Sydney.

—_. 2015. 'Encountering the World of Music: The University's Widening Acknowledgment of Music beyond the Western Canonic Repertoire.' 2015 Public Lecture Series: Milestones in Music. Australia National University. Accessed 20 December 2015. music.anu.edu. $\mathrm{au} / 50$ th/milestones-in-music-stephen-wild. 
This text is taken from A Distinctive Voice in the Antipodes: Essays in Honour of Stephen A. Wild, edited by Kirsty Gillespie, Sally Treloyn and Don Niles, published 2017 by ANU Press, The Australian National University,

Canberra, Australia.

dx.doi.org/10.22459/DVA.07.2017.17 